${ }^{1} S B O R C$ Research Institute for Agriculture of Crimea, 150 Kyivska Str., Simferopol, 295053, Crimea

${ }^{2}$ Institute of Agricultural Microbiology and Agroindustrial Manufacture, NAAS, 97 Shevchenko Str., Chernihiv, 14027, Ukraine

\title{
NEW ARBUSCULAR MYCORRHIZAL FUNGI ASSOCIATIONS FROM SOILS OF CRIMEAN STEPPE
}

The primary selection of arbuscular mycorrhizal (AM) fungi from soils of Crimean Steppe was conducted. The most effective associations P3, P5, S1, S3, S8 and S9 were identified using morphological characteristics of Sorgum sudanense roots colonization and spores surface appearance. It was shown that AM fungi form Arum-type symbiosis contain wellestablished spores' 'kinds specific to individual associations. The molecular identification was performed in addition to the morphological data. AM fungi associations P3, P5, S1, S3, S8 and $S 9$ were identified as Rhizophagus genus while Sl association as Funneliformis genus.

$K$ e y words: arbuscular mycorrhizal fungi, root colonization, spores, identification, $r D N A$.

Application of biopreparations based on effective microorganisms' strains is one of the methods used in sustainable agriculture [8, 12]. Many research studies have proved the positive effect of biopreparations based on AM fungi on crop production $[1,3,13]$. This fact is related to the fungi's ability to colonize plant's roots and enrich inflow of heavy soluble phosphates $[6,14]$ and nitrogen [11] from soil to macrosymbiont. During the evolution these fungi lost their ability to absorb carbohydrates. As the result they need to obtain them through the symbiosis from plants as hexose [18]. Symbiosis with high plants for endomycorrhizal fungi is obligated [20]. Soils of South of Ukraine, specifically Crimean, include representative population of AM fungi [7]. Isolation of new AM fungi associations from natural habitat using analytical selection is one of the concepts used in the production of microbial preparations. Isolated associations are effective in plant-microbe interaction.

Therefore, the aim of this work was to select new AM fungi associations from Steppe Crimea soils and identify their taxonomy.

Materials and methods. Isolation of new AM fungi associations from agrocenosis and natural phytocenosis of Crimean Steppe was performed using Brundrett [1] and Labutova [10] techniques. Impact of new associations' inoculum on Sorgum sudanense (Piper) Stapf (variety Fyoleta, SB NUL\&ES of Ukraine "Crimean Agrotechnological University", Simferopol) mycorrhizae development was performed in a pot experiment on sand with artificial light and regulate watering $[4,10]$. Rhizophagus irregularis BEG144 (ARRIAM RAAS, St. Petersburg) was used as the reference isolate of AM fungi - biopreparation's agent [21]. 21 new AM fungi associations were collected for investigation.

AM fungi inoculums were applied at 150-200 mycorrhiza-making unit per pot rate. Quantification of AM fungi colonization on Sorgum sudanense roots was implemented using Vierheilig et al. (staining root samples) [23] and Trouvelot et al. (quantity) [22] methods. The efficiency of plant-microbe interaction 
was assessed by dry-weight of roots and shoots. [2].

Statistical analysis of data was performed using error of mean calculations

Identification of AM fungi was carried out by microscopy of spore morphology and mycorrhizal development on Sudan grass roots [5]. Complementarily rRNA gene was sequenced. Total DNA was extracted from AMF-colonized roots from pot experiment, using modified CTAB-method. Specific for Glomeromycota primers were applied: SSUGlom 1 (5'-ATTACGTCCCTGCCCTTTGTACA-3') and LSU-Glom 1 (5'-CTTCAATCGTTTCCCTTTCA-3') [16]. These primers were used for amplification of the 18S rRNA (partial) - ITS1 - 5.8S rRNA - ITS2 - 28S rRNA (partial) gene region. PCR was conducted in $25 \mu \mathrm{l}$ reaction volume containing $2.5 \mu \mathrm{l}$ buffer for polymerase, $0.2 \mathrm{mM}$ of each dNTPs, $2.8 \mathrm{mM} \mathrm{MgCl}, 5 \mathrm{pM}$ of each primers, 1 units of Taq polymerase (Evrogen, Russia), $\approx 20 \mathrm{ng}$ of target DNA. Programmable Thermal Controller (iCyclerÔ, Bio-rad, USA) with 35 cycles of $94^{\circ}$ for $30 \mathrm{~s}, 55^{\circ}$ for $30 \mathrm{~s}$ and $72^{\circ}$ for 1 min with a final extension step of 5 min was used. Electrophoresis of PCR products was run in a $1 \%$ agarose gel. DNA was visualized by ethidium bromide staining.

PCR products were cloned in Echerichia coli DH5 $\alpha$ using pTZ57R/T vector from InsT/AcloneÔ PCR Product Cloning Kit (Fermentas, USA). The bluewhite screen and PCR with M13 primers were used for detection of recombinant bacteria with cloned insertion. Sequencing was conducted using CEQÔ 8000 Genetic Analysis System (Beckman Coulter, USA) in according to the manufacturer's protocol. Similarities between sequences were determined using the BLAST service provided by GenBank. Sequences were aligned with other published Glomeraceae sequences using the ClustalW. Further visual alignment was performed in Mega 3 software package.

Results and discussions. New arbuscular mycorrhizal fungi associations were selected from Crimean Steppe soils. 21 associations were collected from mycorrhiza formed in agroecosystems of Glycine max (L.) Merr, Medicágo sativa (L.), Phaseolus vulgaris (L.) and in natural ecosystems of Onobrýchis sp., Trifolium sp., Medicágo sp., Vicia sp., Setaria sp., Artemisia sp. and Thymus sp. First screenings have shown that 7 associations are capable of intense plant roots colonization with $90-100 \%$ occurrence frequency.

The efficiency of AM fungi associations was verified on $S$. sudanense plants in the pot experiment. There was no mycorrhiza in the nontreated control (Tab. 1). The reference isolate $R$. irregularis BEG144 and new associations S5, S9, P5 had formed mycorrhizal structure on plant roots with higher rate than in another treatments: intensity of mycorrhizal colonization and arbuscule abundance was higher in 1.2 - 6.6 times; vesicle abundance - from 1.6 to 23.8 times. The root dry-biomass of host plant and the mycorrhiza development intensity are an important characteristics of biopreparations based on AM fungi. The greatest effect was showed in variants with new associations S5, S8, S9, P5, where application of AM fungi inoculum had increased the root drybiomass from 2.4 to 2.8 times comparing to control and from 1.9 to 2.3 times comparing to the $R$. irregularis BEG144 strain. Furthermore, S1, S5, S9, P5 associations have also influenced the increase of shoot dry-biomass of plants up to $133.3-216.7 \%$ and $16.7-58.3 \%$ in variants without treatment and treated with reference isolate, respectively. 
Table 1

Efficiency of $S$. sudanense inoculation by arbuscular mycorrhizal fungi (pot experiment on sterile sand)

\begin{tabular}{|c|c|c|c|c|c|}
\hline Treatment & $\begin{array}{c}\text { M, } \\
\% / \mathrm{cm} \text { root }\end{array}$ & $\begin{array}{c}\text { A, } \\
\% / \mathrm{cm} \text { root }\end{array}$ & $\begin{array}{c}\text { B, } \\
\% / \mathrm{cm} \text { root }\end{array}$ & $\begin{array}{c}\text { Root } \\
\text { dry-biomass, } \\
\text { g/plant }\end{array}$ & $\begin{array}{c}\text { Shoot } \\
\text { dry-biomass, } \\
\text { g/plant }\end{array}$ \\
\hline Control & 0 & - & - & $0.26 \pm 0.13$ & $0.06 \pm 0.02$ \\
\hline \multicolumn{6}{|c|}{ Reference isolate } \\
\hline BEG 144 & $69.3 \pm 15.9$ & $44.9 \pm 27.9$ & $1.0 \pm 0.5$ & $0.32 \pm 0.04$ & $0.12 \pm 0.01$ \\
\hline \multicolumn{7}{|c|}{ New associations } \\
\hline S1 & $39.1 \pm 36.8$ & $30.4 \pm 33.1$ & $2.1 \pm 2.1$ & $0.49 \pm 0.21$ & $0.14 \pm 0.01$ \\
\hline S5 & $53.6 \pm 32.9$ & $28.2 \pm 18.7$ & $11.0 \pm 2.2$ & $0.70 \pm 0.10$ & $0.15 \pm 0.02$ \\
\hline S8 & $55.2 \pm 5.5$ & $22.3 \pm 3.2$ & $6.9 \pm 1.8$ & $0.62 \pm 0.16$ & $0.11 \pm 0.05$ \\
\hline S9 & $71.9 \pm 5.5$ & $48.0 \pm 8.5$ & $47.5 \pm 6.2$ & $0.65 \pm 0.01$ & $0.17 \pm 0.01$ \\
\hline P2 & $46.3 \pm 22.3$ & $23.4 \pm 24.7$ & $6.4 \pm 5.8$ & $0.13 \pm 0.01$ & $0.10 \pm 0.04$ \\
\hline P3 & $16.8 \pm 15.3$ & $7.3 \pm 4.6$ & $2.0 \pm 1.9$ & $0.37 \pm 0.09$ & $0.11 \pm 0.02$ \\
\hline P5 & $55.5 \pm 5.1$ & $34.2 \pm 3.5$ & $26.6 \pm 1.0$ & $0.72 \pm 0.05$ & $0.19 \pm 0.03$ \\
\hline
\end{tabular}

Note: $\mathrm{M}$ - intensity of mycorrhizal colonization;

A - arbuscule abundance;

$\mathrm{B}$ - vesicle abundance.

The identification of new associations is a necessary step for their subsequent use. All this associations belongs to the form of Arum-type mycorrhiza, like $\mathrm{S} 5$ and P3 shown in fig. 1. Substantially, arbuscules had cylindrical stem with dichotomy branches, which got tighten by diameter to terminal end. Most of vesicles were thin-walled and have ellipsoidal shape. The amount and time of their appearance had varied depending on the environmental conditions and associations used. Intraradical hypha had spread in parallel to lengthwise root's axis, in rare cases they were curled, except for the areas around the infection penetration places. Hypha were transversally connected by lateral branches. Frequently, the infected areas had melded to form continuous colonization of plant's roots. Olden mycorrhiza was mostly presented by hypha and generous amount of vesicles.

Spores were produced singly or/and in aggregates terminally on extraradical hypha. The association P3 had single type of spores, $\mathrm{S} 1-3$ types, $\mathrm{S} 5-3$ types,
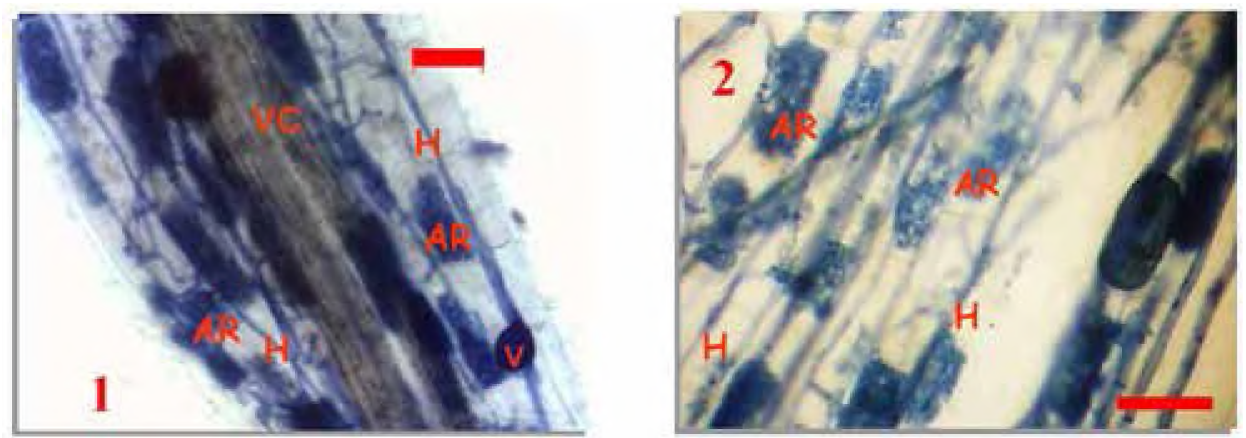

Fig. 1. Mycorrhiza development of new AM fungi associations S5 (1) and P3 (2) in S. sudanense roots

Note: $\mathrm{AR}$ - arbuscules; $\mathrm{H}$ - hypha; V - vesicle; VC - vascular cylinder. Scale bar $=50 \mu \mathrm{m}$. 
S8 - 1 type, S9 - 2 types. Circular and slightly oval shapes were observed, but of the different sizes (from $40.5 \mu \mathrm{m}$ to $228.6 \mu \mathrm{m}$ ) and colors (fig. 2).

The spore wall consists of several layers had continued with a wall of the subtending hypha. Sometimes intraradical spores were observed instead of vesicles. Such mycorrhizal development on roots and spores forms indicate that new isolated associations belong to the Glomeraceae family [5].

Sequencing of rDNA and internal genomic spacer (ITS) is one of the most precise methods to identify of AM fungi systematic position. Therefore, the total DNA was extracted from isolated associations. Partial rRNA genes were amplified from all extracted DNA with specific SSU-Glom1/ LSU-Glom1 primers. Obtained products were about $1080 \mathrm{bp}$ length (fig. 3). Given size of products corresponds with other GenBank rDNA sequences of AM fungi.

14 PCR-fragment from 7 association were cloned into the target rDNA sequences. Obtained sequences were submitted to the GenBank. Associations P3, P5, S1 (clone G04), S8, S9 were identified as Rhizophagus irregularis while association S1 (clone C04) were identified as Funneliformis mosseae based on BLAST-analysis of partial rDNA sequence (Table 2). Systematic position in Glomeromycota genus of associations S3 (clone A05), S3 (clone D05), S5 by BLAST was not identified.

The phylogenetic tree was constructed in order to describe the taxa position of new associations. All genera of the Glomeraceae family (allocated nowadays $[15,19]$ ) and Acaulosporaceae (out-group) were used for construction of the phylogenetic tree. Totally, 271 sequences from GenBank were employed (Fig. 4). The phylogenetic tree corroborated these associations had shown the
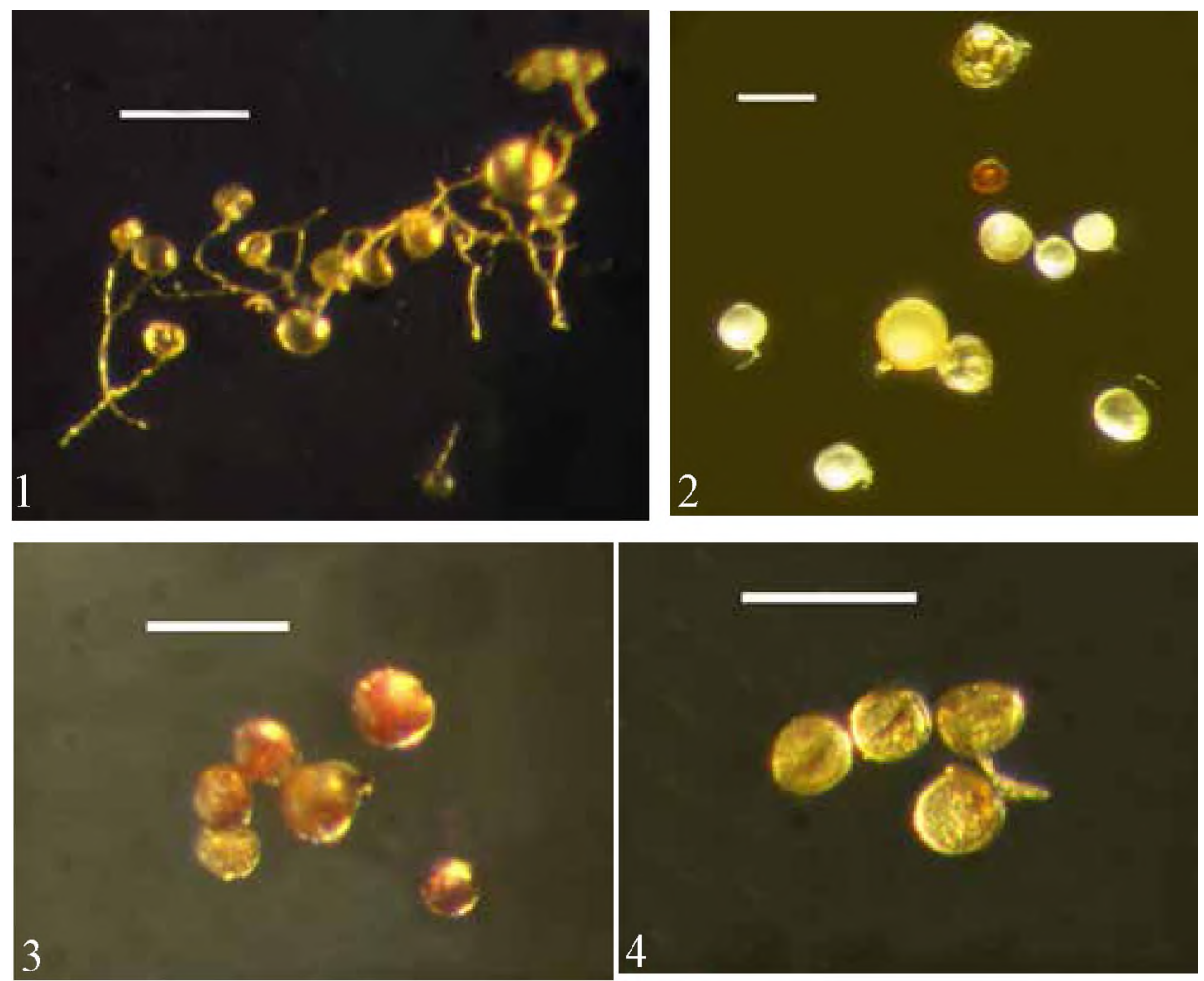

Fig. 2. Spores formed by associations P3 (1), S1 (2), S5 (3) and S9 (4) Note: Scale bar $=200 \mu \mathrm{m}$. 


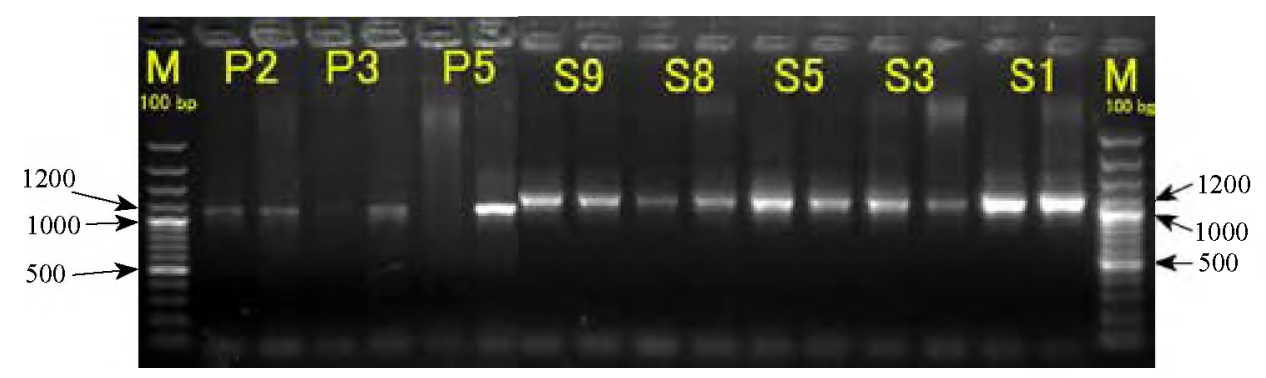

Fig. 3. rDNA PCR-products of AM fungi associations,amplified using SSU-Glom1/ LSU-Glom1 primers

Marker: Gene Ruler Mix (Fermentas)

Table 2 Comparison partial rRNA gene of AM fungi associations with GenBank

\begin{tabular}{|c|c|c|}
\hline Association & $1^{\text {st }}$ BLAST result in GenBank & Identities \\
\hline $\begin{array}{c}\text { P3 } \\
\text { KM376420 }\end{array}$ & $\begin{array}{l}\text { Rhizophagus irregularis DAOM229456, } \\
\text { isolate spore 3, clone 03I2_16_29 }\end{array}$ & $\begin{array}{l}5^{\prime}-490 / 513(96 \%) \\
3^{\prime}-508 / 515(99 \%)\end{array}$ \\
\hline $\begin{array}{c}\text { P5 } \\
\text { KM376421 }\end{array}$ & Rhizophagus irregularis clone pMK100-4 & Full - 1048/1103(95\%) \\
\hline $\begin{array}{c}\text { S1 C04 } \\
\text { KM376419 }\end{array}$ & $\begin{array}{l}\text { Funneliformis mosseae isolate Att109-28, } \\
\text { clone pCK081-11. }\end{array}$ & $\begin{array}{l}5^{\prime}-223 / 237(94 \%) \\
3^{\prime}-579 / 588(98 \%)\end{array}$ \\
\hline $\begin{array}{c}\text { S1 G04 } \\
\text { KM376418 }\end{array}$ & $\begin{array}{l}\text { Rhizophagus irregularis isolate from } \\
\text { Poland (trap culture), clone pMK 108-5 }\end{array}$ & $5^{\prime}-416 / 435(96 \%)$ \\
\hline $\begin{array}{c}\text { S3 A05 } \\
\text { KM376417 }\end{array}$ & $\begin{array}{l}\text { Uncultured Glomeromycota clone } \mathrm{KP}_{-} \\
\mathrm{C} 033\end{array}$ & $\begin{array}{l}5^{\prime}-180 / 190(95 \%) \\
3^{\prime}-629 / 636(99 \%)\end{array}$ \\
\hline $\begin{array}{c}\text { S3 D05 } \\
\text { KM376416 }\end{array}$ & Glomus sp. 8 SUN-2011 isolate $08 \_7 \_10$ & $5^{\prime}-657 / 660(99 \%)$ \\
\hline $\begin{array}{c}\text { S5 } \\
\text { KM376415 }\end{array}$ & Glomus sp. 8 SUN-2011 isolate $08 \_6 \_11$ & $3^{\prime}-583 / 591(99 \%)$ \\
\hline $\begin{array}{c}\text { S8 } \\
\text { KM376414 }\end{array}$ & $\begin{array}{c}\text { Rhizophagus irregularis strain } \\
\text { DAOM181602, clone EI2_7_29 }\end{array}$ & $5^{\prime}-491 / 510(96 \%)$ \\
\hline $\begin{array}{c}\text { S9 } \\
\text { KM376422 }\end{array}$ & $\begin{array}{l}\text { Rhizophagus irregularis DAOM181602, } \\
\text { isolate spore 1, clone EI2_3_6 }\end{array}$ & $\begin{array}{l}5^{\prime}-452 / 474(95 \%) \\
3^{\prime}-544 / 569(96 \%)\end{array}$ \\
\hline
\end{tabular}

systematic position of rDNA of isolated AM fungi associations. Associations P3, P5, S1, S3, S8, S9 were located in Rhizophagus cluster, C04 clone from S1 association was located in Funneliformis cluster.

Thus, the morphological and molecular identification had ascertained the taxonomy of AM fungi comprised in new associations. It was shown that new associations P5, S5, S9 were highly effective. They have increased the biomass of Sorghum sudanence roots and the mycorrhiza development, indicating that these associations can be applied in plants biotechnology.

The authors would like to express gratitude to A.G. Pinaev, O.Yu. Shtark, G.A. Akhtemova, A.Yu. Borisov and other staff of the ARR Institute for Agricultural Microbiology and V.S. Zotov (A.N. Bakh Institute of Biochemistry) for assistance in molecular data receipt. 


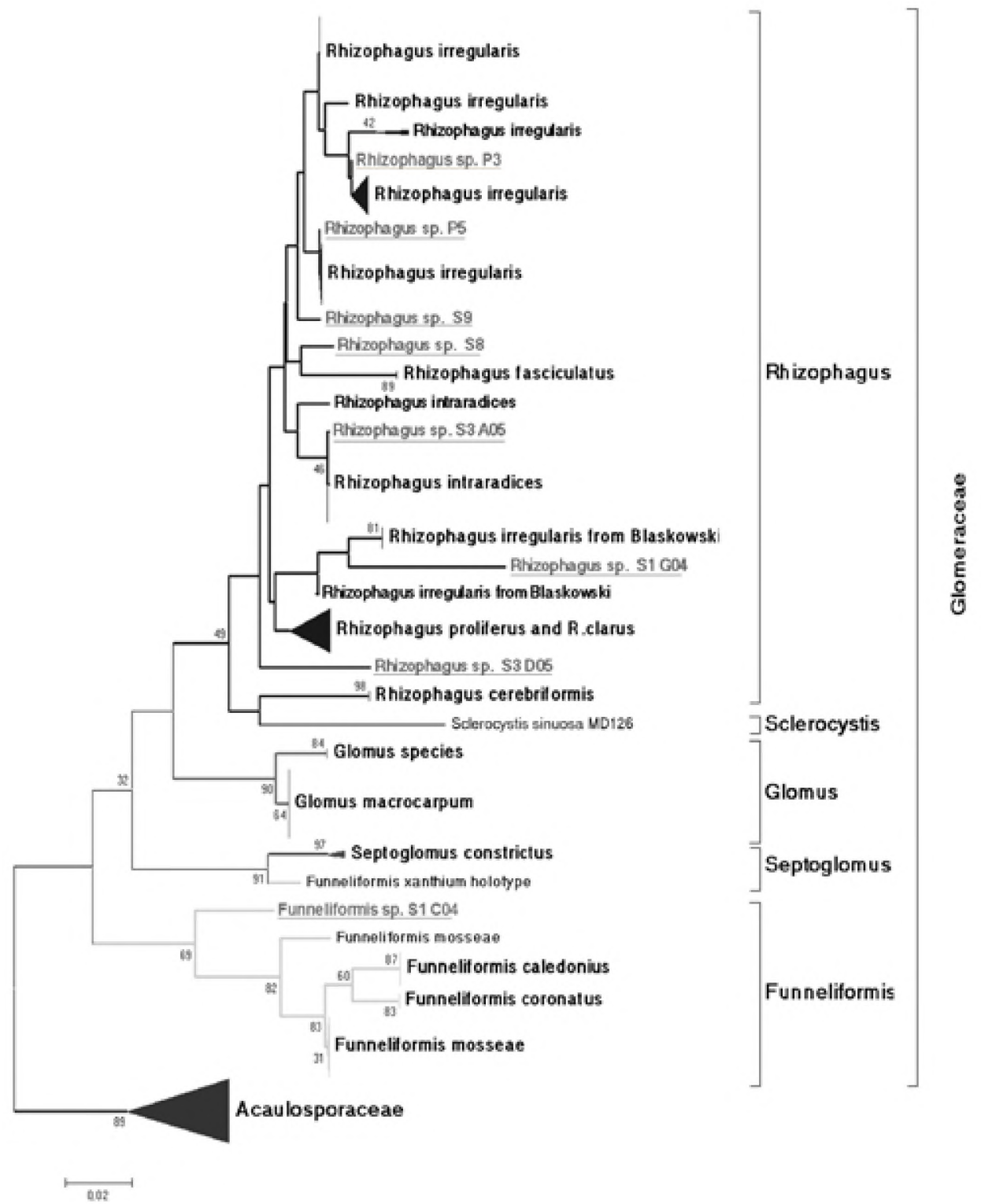

Fig. 4. Phylogenetic tree showing the systematic position of rDNA of AM fungi associations (names are underlined), constructed using neighbor-joining methods based on Kimura 2-parameter model. Numbers on branches show the bootstrap support for the respective topologies

\section{С.Ф. Абдураиитов ${ }^{1}$ В.В. Волкогон ${ }^{2}$}

${ }^{1}$ Науково-дослідний інститут сільського господарства Крилу, вул. Київська, 150, Сімферополь, 290053, АР Крим

${ }_{2}^{2}$ Інститут сільськогосподарської мікробіології та агропромислового виробнищтва НААН, вул. Шевченко, 97, Чернігів, 14027, Украӥна

\section{НОВІ АСОЦІАЦІї ГРИБІВ АРБУСКУЛЯРНОЇ МІКОРИЗИ ІЗ ГРУНТІВ СТЕПУ КРИМУ}

$\mathrm{P}$ е 3 ю м е

В роботі проведена первинна селекція грибів арбускулярної мікоризи (AM) із грунтів степного Криму. Найефективніші асоціації P3, P5, S1, S3, S8, S9 ідентифіковані за морфологічними особливостями колонізації коренів суданської трави та 
зовнішнім виглядом спор. При цьому виявлено, що всі досліджені гриби АМ формують Arum-тип симбіозу і мають види спор, характерні для окремих асоціацій. За використання молекулярно-біологічних методів показано, що до складу асоціацій P3, P5, S1, S3, S8, S9 входять представники роду Rhizophagus, а до складу S1 - також i Funneliformis.

К л ю ч о в і с ло в а: гриби арбускулярной мікоризи, колонізація коренів, спори, ідентифікачіл, рДНК.

\section{С.Ф. Абдурашитов ${ }^{1}$, В.В. Волкогон ${ }^{2}$}

${ }^{1}$ Научно-исследовательский институт сельского хозяйства Крыма, ул. Киевская, 150, Симферополь, 290053, АР Крым

${ }^{2}$ Ннститут сельскохозяйственной микробиологии и агропромышленного производства НААН, ул. НКевченко, 97, Чернигов, 14027, Украина

\section{НОВЫЕ АССОЦИАЦИИ ГРИБОВ АРБУСКУЛЯРНОЙ МИКОРИЗЫ ИЗ ПОЧВ СТЕПИ КРЫМА}

$\mathrm{P}$ е 3 ю м е

В работе проведена начальная селекция грибов арбускулярной микоризы (АМ) из почв степного Крыма. Наиболее эффективные ассоциации Р3, P5, S1, S3, S8, S9 были идентифицированы по морфологическим особенностям колонизации корней суданской травы и внешнему виду спор. При этом выявлено, что все исследованные грибы АМ формируют Arum-тип симбиоза и содержат устоявшиеся виды спор, характерные для отдельных ассоциаций. При использовании молекулярно-биологических методов показано, что в состав ассоциаций P3, P5, S1, S3, S8, S9 входят представители рода Rhizophagus, а в состав S1 - также и Funneliformis.

К л ю ч е в ы е с л о в а: грибы арбускулярной микоризы, колонизация корней, споры, идентификачия, $р Д Н К$.

1. Brundrett M., Bougher N., Dell B., Grove T. and Malajczuk N. Working with Mycorrhiza in Forestry and Agriculture. - Canberra: ACIAR, 1996. - 374 p.

2. Dospehov B.A. Manual of field experiment. - M: Agropromizdat, 1985. -352 p.

3. Gosling P., Hodge A., Goodlass G., Bending G.D. Arbuscular mycorrhizal fungi and organic farming // Agr. Ecos.Env. - 2006. - 113 - P. 17-35.

4. Hoagland D.R., Arnon D.I. The waterculture method for growing plants without soil. - California: Agr. Exp. Sta., 1950. - Circular 347. - 32 p.

5. Identification to genus / http://invam.wvu.edu/the-fungi/classification

6. Javot H., Penmetsa R.V., Terzaghi N., Cook D.R., Harrison, M.J. A Medicago truncatula phosphate transporter indispensable for the arbuscular mycorrhizal symbiosis // Proc. Natl Acad. Sci. USA. - 2007. - 104. - P. 1720-1725.

7. Kosenko N.M., Andreeva N.O., Patika V.P. Endomycorrhizal fungi in southern Ukraine soils // Zemlerobstvo. - 1994. - 70. - P. 91-95.

8. Kurdish I.K. The introduction of microorganisms in agroecosystems. - Kiev: Naukova dumka, 2010. $-255 \mathrm{p}$.

9. Labutova N.M. Interactions between endomycorrhizal fungi and rhizosphere microorganisms // Myc. and phytopath. - 2009. - 43 (1). - P. 3-19.

10. Labutova N.M. Manual for arbuscular mycorrhizal fungi investigation. - St. Petersburg: 
ARIPP, 2000. - $24 \mathrm{p}$.

11. Lopez-Pedrosa A., Gonzalez-Guerrero M., Valderas A., Azcon-Aguilar C., Ferrol N. GintAMT1 encodes a functional high-affinity ammonium transporter that is expressed in the extraradical mycelium of Glomus intraradices // Fungal Genet. Biol. - 2006. 43. - P. 102-110.

12. Volkohon V.V., Nadkernichna O.V., Kovalevska T.M., Tokmakova L.M., Kopilov E.P., Kozar S.F., Tolkachov M.Z., Melnichuk T.N., Chaykovskaya L.O., Sherstoboev M.K. et al. Microbe preparations in agriculture. Theory and practice. Monograph. Ed. by Volkohon V. - Kiev: Agrarna nauka, 2006. - 312 p.

13. Mycorrhizal Technology in agriculture. Ed. by S. Gianinazzi, H. Schupp, J.M. Barea, K. Hasalwandter. - Bazel: Springer, 2002. - 296 p.

14. Poulsen K.H., Nagy R., Gao L.L., Smith S.E., Bucher M., Smith F.A., Jakobsen I. Physiological and molecular evidence for Pi uptake via the symbiotic pathway in a reduced mycorrhizal colonization mutant in tomato associated with a compatible fungus // New Phytol. - 2005. - 168. - P. 445-453.

15. Redecker D., Schüßler A., Stockinger H., Stürmer S.L., Morton J.B., Walker C. An evidence-based consensus for the classification of arbuscular mycorrhizal fungi (Glomeromycota) // Mycorrhiza. - 2013. - 23. - P. 515-531.

16. Renker C., Heinrichs J., Kaldorf M., Buscot F. Combining nested PCR and restriction digest of the internal transcribed spacer region to characterize arbuscular mycorrhizal fungi on roots from the field // Mycorrhiza. - 2003. - 13 - P. 191-198.

17. Sambrook J., Russell D.W. Molecular cloning: a laboratory manual [3rd ed.]. - New York: Cold Spring Harbor, 2001. - 1. - 749 p.

18. Schüßler A., Martin H., Cohen D., Fitz M., Wipf D. Characterization of a carbohydrate transporter from symbiotic glomeromycotan fungi // Nature. - 2006. - 444. P. 933-936.

19. Schüßler A., Walker C. The Glomeromycota: a species list with new families. Edinburgh, Munich, Oregon, 2010. - 46 p.

20. Smith S.E., Read D.J. Mycorrhizal symbiosis [2nd ed.]. - London: Academic Press. 1997. $-605 \mathrm{p}$.

21. Shtark O.Y., Danilova T.N., Naumkina T.S., Vasilchikov A.G., Chebotar V.K., Kazakov A.E., Zhernakov A.I., Nemankin T.A., Prilepskaya N.A., Borisov A.Y. et al. Analysis of pea (Pisum sativum L.) source material for breeding of cultivar with high symbiotic potential and choice of criteria for its evaluation // Ecol. genetic. -2006 . -4 № 2. P. 22-28.

22. Trouvelot A., Kough J.L., Gianinazzi-Pearson V. Mesure du taux de mycorhization VA d'un systeme radiculaire. Recherche de methodes d'estimation ayant une signification. Physiological and genetical aspects of mycorrhizae; eds. Gianinazzi-Pearson V., Gianinazzi S. - Paris: INRA, 1986. - P. 217-221.

23. Vierheilig H., Coughlan A.P., Wyss U., Piché Y. Ink and Vinegar, a Simple Staining Technique for Arbuscular-Mycorrhizal Fungi. // Applied and Environ. Microbiol. ASM. - 1998. - 64. - P. 5004-5007.

Отримано 16.09.2015 